\title{
Crop Systems, Quality and Protection of Diplotaxis tenuifolia
}

\author{
Gianluca Caruso ${ }^{1}$, Giuseppe Parrella ${ }^{2}$ (D), Massimo Giorgini ${ }^{2}$ (i) and Rosario Nicoletti ${ }^{1,3, *(1)}$ \\ 1 Dipartimento di Agraria, Università degli Studi di Napoli ‘Federico II', Via Università 100, 80055 Portici, \\ Italy; gcaruso@unina.it \\ 2 Istituto per la Protezione Sostenibile delle Piante, Consiglio Nazionale delle Ricerche, Via Università 133, \\ 80055 Portici, Italy; giuseppe.parrella@ipsp.cnr.it (G.P.); massimo.giorgini@ipsp.cnr.it (M.G.) \\ 3 Consiglio per la Ricerca in Agricoltura e l'Analisi dell'Economia Agraria, Centro di Ricerca Olivicoltura, \\ Frutticoltura e Agrumicoltura, 81100 Caserta, Italy \\ * Correspondence: rosario.nicoletti@crea.gov.it; Tel.: +39-081-253-9199
}

Received: 8 March 2018; Accepted: 2 April 2018; Published: 5 April 2018

\begin{abstract}
Perennial wall-rocket (Diplotaxis tenuifolia (L.) D.C.) is a herbaceous plant belonging to the Brassicaceae with a cosmopolitan distribution. Traditionally harvested as a spontaneous herb, today it is a crop species of increasing importance after the diffusion of the ready-to-use salads in the vegetable retail markets. Besides relevance as a food crop, its consumption is prompted by consideration in the traditional medicine of several peoples in the native areas of the Mediterranean and western Asia based on recognized health beneficial effects. In fact, the leaves have notable nutritional properties related to their contents of glucosinolates and some antioxidant compounds, such as vitamin $C$ and flavonoids, which entitle their dietary inclusion for the prevention of cancer and cardiovascular diseases. This paper provides an overview on aspects concerning the biology, crop management, nutritional properties, industrial processing and uses of perennial wall-rocket.
\end{abstract}

Keywords: perennial wall-rocket; ready-to use-salads; glucosinolates; antioxidants

\section{Introduction}

Diplotaxis tenuifolia (L.) D.C. is a species belonging to the Brassicaceae, known as 'rocket' or 'arugula'; in Italy the common name 'rucola selvatica' (wild rocket) is prevalent, in contrast to the name 'rucola coltivata' (cropped rocket), which refers to the species Eruca sativa Miller (syn. E. vesicaria (L.) Cav.). The specific common name of 'perennial wall-rocket' is currently preferred for discrimination from other species in the genus Diplotaxis, while the name 'Lincoln weed' or 'sand rocket' is more commonly used in Australia where the species is mainly regarded as a problematic weed [1].

The economic interest in growing perennial wall-rocket has increased as a consequence of the progressive diffusion of ready-to-use salads, the so-called 'fourth generation vegetables', which is a commercialization pattern effective in preserving the freshness and typical scent of the leaves, thus extending their shelf life and market availability. Until two decades ago, E. sativa was the prevalent cropped rocket species, while D. tenuifolia was mostly harvested as a spontaneous herb. Nowadays, thanks to its smoother and more succulent leaves that have encountered consumer preference, perennial wall-rocket has spread in most agricultural areas, covering a surface of about 4000 ha in Italy according to the latest estimation [2]. Aspects concerning biology, properties, cultivation, processing and uses of the product are reviewed in this paper. 


\section{Notes on Taxonomy and Biology}

Phylogenetically close to the genus Brassica [3], the genus Diplotaxis (tribe Brassicae, subtribe Brassicinae) includes about 30 species originating from the Mediterranean area, particularly from the western part of the basin which is considered its centre of diversity [4]. The species belonging to Diplotaxis are morphologically similar, and present leafy to subscapose stems bearing entire to pinnately lobed or toothed leaves (Figure 1). D. tenuifolia and a few related species have brochidromous yellow petals and siliques with a seedless beak, which are regarded as distinctive features. Unlike most Diplotaxis species which are annual, D. tenuifolia is characterized by a perennial growth habitus which makes it more suitable as a crop plant, since novel foliage from the adventitious buds scattered on its roots can regrow after each harvest. The taxon D. cretacea, formerly considered a subspecies of D. tenuifolia and more widespread in Ukraine as well as in Southern Russia [5], is now recognized as a separate species [6]. The species Diplotaxis muralis (L.) DC is also edible, but mainly collected from the wild since it has not spread in cultivation so far, and its common name (wall rocket) is indicative of a close similarity with $D$. tenuifolia; these two species can be distinguished considering that $D$. muralis has more oval cotyledons, thinner leaves, smaller petals in pale yellow flowers, and bristly hairs on the lower part of the stem [4,7]. Differences are also reported in their breeding systems [8], and caryotype: in fact, D. tenuifolia is diploid $(n=11)$, while D. muralis $(n=21)$ is an allotetraploid derived from hybridization between $D$. tenuifolia and D. viminea $(\mathrm{L}$.) DC $(n=10)$ [9]. The allotetraploid condition is also supported by observations on the seed coat pattern [10], and by studies concerning the photosynthetic type, which is C3 in D. viminea and C3-C4 intermediate in D. tenuifolia [11]. The latter system is more efficient and allows for an enhanced $\mathrm{CO}_{2}$ assimilation [12].

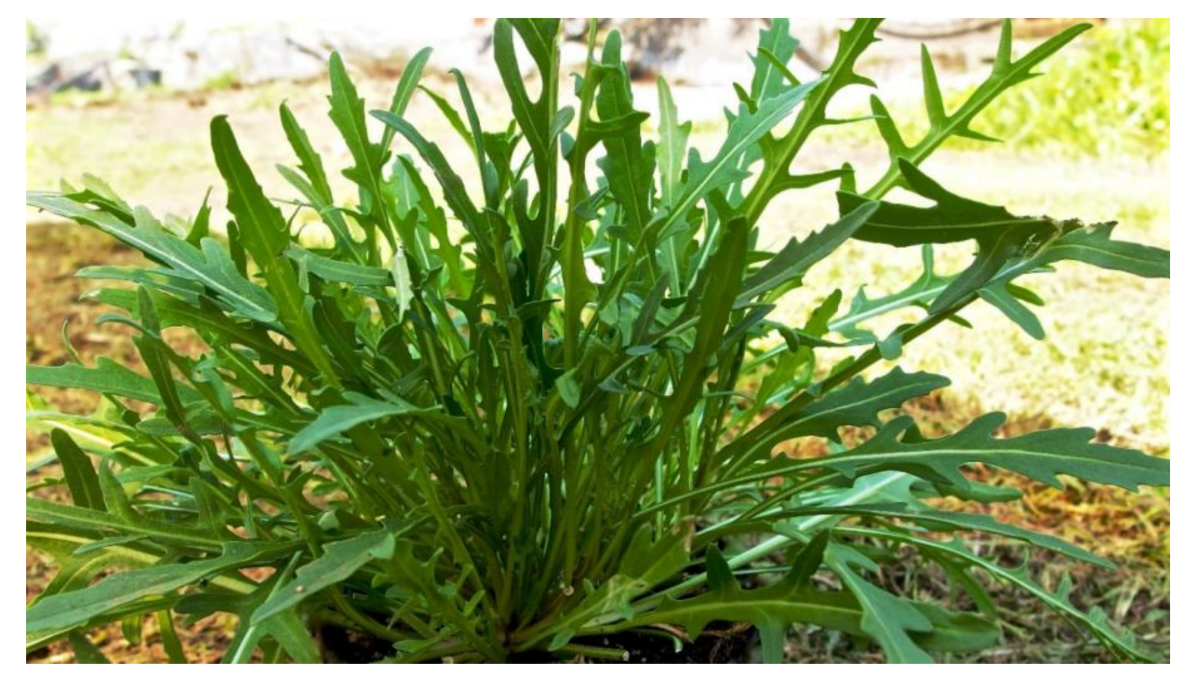

Figure 1. Perennial wall-rocket plant at the pre-harvest stage.

In Italy, D. tenuifolia spontaneously thrives along coastal areas at altitudes below $400 \mathrm{~m}$. It is well adapted to harsh and calcareous soil, although sandy-loam soil with a good drainage capacity is preferred [13]; moreover, it has been classified as salt-tolerant after its capacity to bear concentrations of $\mathrm{NaCl}$ up to $300 \mathrm{mM}$ [14]. Sensitivity to excess boron in alkaline soils has been reported, after symptoms of toxicity were observed at a concentration of $12.2 \mathrm{mg} \mathrm{kg}^{-1}$ [15]. Perennial wall-rocket is a cool-season crop showing a faster growth rate and development under increasing day-length and temperature in the range of 2 to $25{ }^{\circ} \mathrm{C}$ [16]. Plants regrow upon leaf cutting $3-5 \mathrm{~cm}$ above the soil surface, due to their ability to store and utilize carbohydrate reserves in the tap root, allowing for new buds and shoot emission at plant base [17].

Apart from cropping reasons, the cosmopolitan distribution of D. tenuifolia results from its adaptability and propagation ease, so that its invasive behaviour has been regarded as a case study [18]. 
Its strong competitive ability in floristic communities is also related to the production of allelopathic substances, such as S-glucopyranosyl thiohydroximate [19]. In Australia the species is considered a noxious weed, particularly in areas where it has invaded poor pastures to such an extent to be possibly responsible for poisoning livestock [1]. Similar problems have also been reported in Argentina [20,21] and North America, where its spread in New York city and vicinities was recorded since the 19th century in consequence of ship trading from Europe [22]. The relevance as a weed also introduces a reasonable concern about the risk of possible transfer of herbicide resistance genes which have been introduced in some cultivated Brassicaceae known to be able to hybridize with D. tenuifolia $[23,24]$. Finally, due to its ability to spread as a weed, it has been considered as an indicator of contamination by heavy metals in industrial and road neighbouring areas [25].

\section{Biochemical and Nutraceutical Properties}

Leaves of perennial wall-rocket are characterized by a bitter or pungent taste deriving from their content of glucosinolates, and a strong acrid aroma depending on the release of volatile isothiocyanates $[26,27]$. Particularly, compounds such as dimeric glucosativin and progoitrin/epiprogoitrin are considered to play a major role in defining the particular savour of rocket salad [27], which is well accepted by consumers [28]. The volatile compound 5-dimethylsulphonium pentanoic acid, which was first extracted from flowers of D. tenuifolia [29], has rather resulted as an extraction artefact [30].

Glucosinolates are a class of $\beta$-thioglucoside- $N$-hydroxysulfates typical of the Brassicaceae including about 130 compounds differing in the chemical structure of their side chain (Figure 2), which release isothiocyanates upon hydrolysis catalyzed by the enzyme myrosinase [31-33]. Improvements in the extraction and analytical methods have been carried out for a more accurate quantitative determination of these substances in both plant tissues and soil [34,35]. With a high variability in the content of glucosinolates reported within the genus Diplotaxis [36], D. tenuifolia belongs to the species cluster showing lower contents, with a range of $0.76-3.03 \mathrm{~g} \mathrm{~kg}^{-1}$ dry weight [27]. However, the total glucosinolate content is also influenced by a season effect (lower in June than September) and harvest succession [37]. Referring to specific compounds, perennial wall-rocket reportedly contains high amounts of glucosativin and lower levels of glucoerucin and glucoraphanin; the latter is more abundant in the flowers, while sinalbin is mostly contained in the roots [38-40]. Variation of glucosinolate type and content may also depend on the accession [36,40]. A more detailed list of the several glucosinolates so far detected in D. tenuifolia is reported in Table 1.

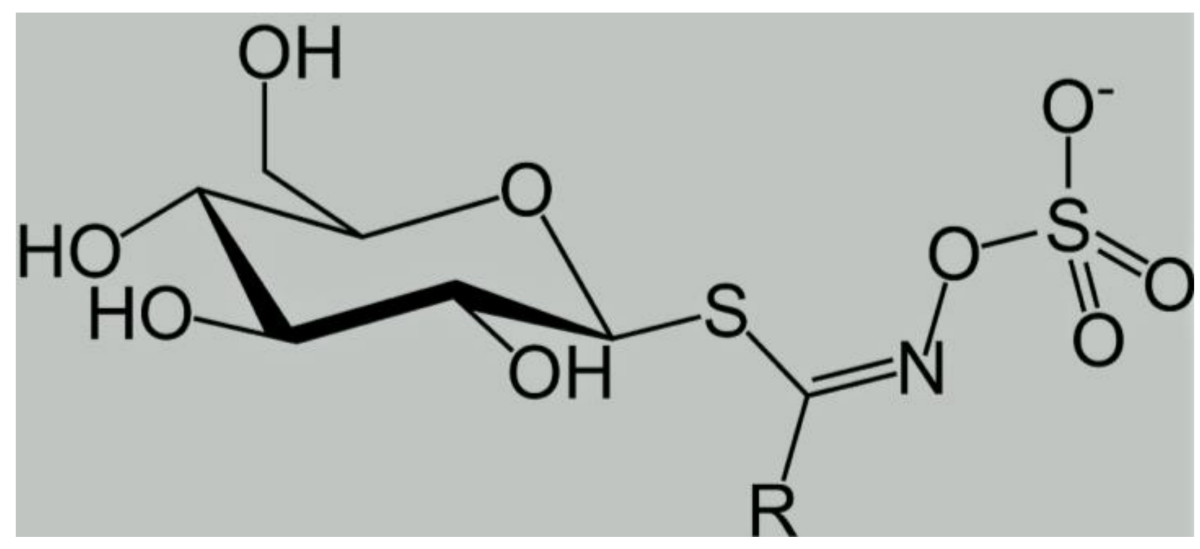

Figure 2. Molecular structure of glucosinolate compounds. R refers to the aglycone moiety (Table 1). 
Table 1. Glucosinolates (GI) reported from D. tenuifolia.

\begin{tabular}{ccc}
\hline Compound Name & Chemical Name (Based on the Aglycone Moiety) & References \\
\hline Diglucothiobeinin & 4-glucopyranosyldisulfanylbutyl-GI & {$[39,41]$} \\
Glucoalyssin & 5-methylsulfinylpentyl-GI & {$[36,39,41,42]$} \\
& 3-hydroxy-5-methylsulfinylpentyl-GI & {$[39]$} \\
Glucoarmoracialafolicin & 4-phenylbutyl-GI & {$[36]$} \\
Glucobrassicanapin & 4-pentenyl-GI & {$[41]$} \\
Glucobrassicin & 3-indolylmethyl-GI & {$[35,36,39,41]$} \\
& 4-hydroxy-3-indolylmethyl-GI & {$[36,39,40]$} \\
Neoglucobrassicin & 4-methoxy-3-indolylmethyl-GI & {$[35,36,38,41]$} \\
Glucoerucin & 1-methoxy-3-indolylmethyl-GI & {$[27,36]$} \\
Glucoibarin & 4-methylthiobutyl-GI & {$[36,38-42]$} \\
Glucoiberverin & 7-methylsulfinylheptyl-GI & {$[40]$} \\
Glucolepidiin & 3-methylthiopropyl-GI & {$[40]$} \\
Gluconapin & ethyl-GI & {$[36,40]$} \\
Gluconasturtiin & 3-butenyl-GI & {$[42]$} \\
Glucoputranjivin & 2-phenethyl-GI & {$[36,41]$} \\
Glucoraphanin & 1-methylethyl-GI & {$[36]$} \\
Glucoraphenin & 4-methylsulfinylbutyl-GI & {$[36,38-42]$} \\
Glucosativin & 4-methylsulfinyl-3-butenyl-GI & {$[40]$} \\
Glucotropaeolin & 4-mercaptobutyl-GI & {$[38,40,42,43]$} \\
Progoitrin/epiprogoitrin & dimeric 4-mercaptobutyl-desulfo-GI & {$[39,40]$} \\
Sinalbin, glucosinalbin & benzyl-GI & {$[36,40]$} \\
Sinigrin & 2-benzoyloxyethyl-GI & {$[39]$} \\
& 2-hydroxy-3-butenyl-GI & {$[39]$} \\
& 4-hydroxybenzyl-GI & {$[36,38,39]$} \\
& 2-propenyl-GI (allyl-GI) & {$[43]$} \\
\hline
\end{tabular}

Cancer chemopreventive activity has been reported for sulforaphane, the aglycone breakdown product of glucoraphanin [44]. Morever, glucoerucin may also be converted to glucoraphanin [45], and glucosinolates themselves have shown some extent of anticancer activity [46]. Arvelexin is another aglycone which has been characterized as a phytoalexin in D. tenuifolia [35], and has interesting colonic anti-inflammatory properties [47]. The glucosinolate content in leaves of $D$. tenuifolia depends on genetic traits, but it is also influenced by cropping practices. In particular, the total content of glucoerucin and glucoraphanin significantly increases with the progress of the cuts [48] and, therefore, the physiological nutrient value of the product tends to improve in the successive harvest rounds. Investigations concerning accessions of $D$. tenuifolia have shown that genetic variation exists within the germplasm which can be exploited for increasing content in these nutraceuticals $[39,40]$.

Isothiocyanates released by the glucosinolates upon their enzymatic degradation are known to protect the plant against many biological adversities; this process has stimulated research aiming to exploit the crop residues as biofumigants [49-51]. In the case of $D$. tenuifolia, experimental evidence has disclosed suppressive effects on mycelial growth of the pathogenic fungus Rhizoctonia solani AG 2-1 in soil amended with very high amounts of green manure $(10 \% w / w)$ [52]. At lower doses (5\%) these effects were observed in the longer term following the increase of microbial activity [53], while even lower doses $(1 \% w / w)$ proved to be effective against the wilt agent Fusarium oxysporum f. sp. radicis-cucumerinum [54]. Field experimentation carried out by incorporating into soil $0.9 \mathrm{~kg} \mathrm{~m}^{-2}$ of dry crop residues significantly reduced propagule survival of Fusarium oxysporum f. sp. radicis-lycopersici, Macrophomina phaseolina and Rhizoctonia solani, while suppression of the root-knot nematode Meloidogyne javanica was only obtained when this treatment was associated with solarization [55]. Finally, infestation by this nematode on roots of tomato and snapdragon was consistently affected by amendments with dry rocket residues [56].

Perennial wall-rocket has slightly higher values of dry matter $\left(90 \mathrm{~g} \mathrm{~kg}^{-1}\right)$ and fibre $\left(9 \mathrm{~g} \mathrm{~kg}^{-1}\right)$ than other salads, but similar nutrient content based on fresh weight, i.e., high levels of potassium ( $4.7 \mathrm{~g} \mathrm{~kg}^{-1}$ fresh product), calcium $\left(3.1 \mathrm{~g} \mathrm{~kg}^{-1}\right)$ and iron $\left(52 \mathrm{mg} \mathrm{kg}^{-1}\right)$ [57]. The total phenolic content in the plant extract has been estimated at $2.9 \mathrm{~g} \mathrm{~kg}^{-1}$ [58], the content of total carotenoids at $129 \mathrm{mg} \mathrm{kg}^{-1}$, 
and that of ascorbic acid at $90 \mathrm{mg} \mathrm{kg}^{-1}[2,59,60]$, which has been shown to accumulate during plant growth [37]. Notably, the recommended daily intakes are 1.6-3.5 $\mathrm{g}$ for potassium, $0.4-1.0 \mathrm{~g}$ for calcium, $15 \mathrm{mg}$ for iron, $0.3-1.0 \mathrm{mg}$ retinol for vitamin A, and 30-60 mg for vitamin C [61].

Ascorbic acid is well-reputed for conferring antioxidant properties, together with flavonoids, carotenoids and xanthophylls, such as lutein [62]. For this reason, diets including rocket leaves are recommended by nutritionists as an aid for preventing cardiovascular and cancer diseases $[63,64]$. With the exception of roots, all $D$. tenuifolia tissues contain polyglycosylated flavonoids whose core aglycone is isorhamnetin, kaempferol, or quercetin [38,65-67], with the latter being prevalent $[39,40,68]$. The occurrence of these products has been also detected in honey deriving from bee-deposited nectar [69]. In addition to the protective role against UV-radiation, their biological function is basically related to resistance to pathogens and pests [70]. Therefore, increasing flavonoid content, expectantly among the primary objectives in perennial wall-rocket breeding, is likely to have beneficial side effects for plant protection. As reported above for glucosinolates, variation in flavonoid content has been found within $D$. tenuifolia germplasm which supports the opportunity of breeding programs for increasing the content of these valuable products [40]. There is also a seasonal influence on flavonoid content, leading to higher concentration in spring-harvested produce [71]. Antioxidant properties also characterize the alkaloid sinapine (4-hydroxy-3,5-dimethoxy-cinnamic acid choline ester) contained in D. tenuifolia seeds, which, however, is better known as an anti-nutritional factor [38,72].

Finally, potential pharmaceutical interest relies on some compounds obtained from leaves of perennial wall-rocket, such as calystegin A5, a nortropane alkaloid derived from pseudotropine [73], and 5-methylthiopentanenitrile, an essential oil possessing antifungal properties [74].

\section{Uses of Product}

The use of perennial wall-rocket as a vegetable has been known in France and Italy at least since the 19th century [4]. Besides representing an ingredient of salads, it is used as a garnish for many dishes, and as a pizza topping; older leaves are too piquant to be consumed raw, but they can be added to soups or sauces. As in other Brassicaceae, breeding may allow for regulating the glucosinolate content in order to obtain a product meeting different consumer tastes. However, so far the number of cultivars is quite reduced if compared to the increasing market demand. Therefore, some efforts have already been made or are in progress aiming to collect new germplasm throughout the Mediterranean area, in the awareness that breeding might provide very profitable results $[13,39,40]$. Rucolino, a liquor prepared in the isle of Ischia and some other areas of Campania, claimed to have digestive and diuretic properties, is also to be considered within the food uses.

Other potential uses of perennial wall-rocket concern seeds, from which an oil can be extracted at $36 \%$ proportion, containing $38.9 \%$ linolenic acid, $22.3 \%$ linoleic acid, $12.6 \%$ oleic acid, and $11.8 \%$ erucic acid $[75,76]$. More recently, a study from Turkey reported a lower oil content $(23-24 \%)$, with the following composition: oleic acid $22.23 \%$, linoleic acid $19.60 \%$, linolenic acid $16.70 \%$, erucic acid $18.79 \%$, eicosenoic acid $9.68 \%$, palmitic acid $8.20 \%$, stearic acid $3.60 \%$ [77]. Although lower than the percentages reported in other cruciferous crops, the high concentration of erucic acid in rocket seed oil discourages its use for human consumption. Technological properties are similar to the taramira or jamba oil extracted from seeds of E. sativa which, especially in the Indian subcontinent, is used in traditional medicine based on its antibiotic properties, in the preparation of soaps, as a lubricant and an illuminating agent $[13,78]$.

In addition to the previously discussed beneficial effect to human health related to the content in sulphoraphane, glucosinolates and flavonoids, the use of D. tenuifolia as a medicinal plant is widely documented in the tradition of several peoples and cultures, and it is still recommended somewhere, mainly as an aphrodisiac or an anti-diarrheic herb [7,13,79-81]. Mucolytic properties are also reported [82], together with pancreatic lipase inhibitory effects which could reduce absorption of lipids, representing an indication for use of perennial wall-rocket in diets for overweight people [58]. 


\section{Farming Practices}

D. tenuifolia is cultivated in open fields or more commonly in greenhouses covered with thermal polyethylene films made of one to five layers and 0.15 to $0.25 \mathrm{~mm}$ thick. The protected environment is even equipped with anti-freezing systems as well as wall and roof openings operated to prevent excessive humidity; shading through net or roof whitening may be needed under excessive light intensity. Perennial wall-rocket can also be grown as a soilless crop, using floating system [83] or nutrient film technique [84]. Yield magnitude is cultivar dependent both in open fields [85] or in greenhouses [2].

Sowing is performed for crops focused on 'baby leaf' manufacturing, whereas transplant is preferred for fresh market crops; in both cases the crop cycles are usually managed from early autumn to spring [2] or from spring to summer, depending on farming system, growing area and commercial demand.

Prior to planting, ploughing or spading of appropriately wet soil is practiced at $30 \mathrm{~cm}$ depth, followed by harrowing, and deep tillage is periodically performed; setting and surface leveling of ridges (1-2 $\mathrm{m}$ in width) are carried out before or concurrently to sowing. It is useful to practice green manure along with solarization and adopt crop rotation, however taking into account that rocket may exert allelopathic effects on plants belonging to Papilionaceae, Apiaceae, Cucurbitaceae and Solanaceae.

When the crop is used for baby leaf produce, sowing is performed mechanically in continuous rows $5 \mathrm{~cm}$ apart at $3-5 \mathrm{~mm}$ depth, with the plant density ranging from 1800 plants $\mathrm{m}^{-2}$ in winter to 2800 plants $\mathrm{m}^{-2}$ in summer, using 7 to $8 \mathrm{~kg} \cdot \mathrm{ha}^{-1}$ seeds, respectively [86]. Crop emergence occurs four days after sowing on average, depending on the sowing period and pattern, and rolling should follow seeding in light soils. Soil surface leveling is needed in order to guarantee a more uniform seed depth as well as to ease mechanical harvest.

In the case of fresh market destination, the ridges are mulched with a black polyethylene or biodegradable film allowing for a crop cycle reduction, a better weed and pest management and an improved produce quality; under the mulch, drip pipes are placed in alternate rows. In the latter crop system, transplant of multi-seeded alveoli (15-25 seeds per hole) is performed, after the 3 leaf plantlets have been reared for a period of 20-30 days in alveolar containers filled with a peat-vermiculite medium. The spacing is $20 \mathrm{~cm}$ between the rows and 10 to $15 \mathrm{~cm}$ between the plants along each row,

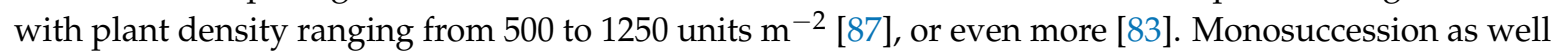
as precession with bean, celery, cucurbits and Solanaceae species is not recommended, as the latter reportedly have a detrimental effect on yield [7,87].

Nutritional requirements of perennial wall-rocket are modest, as $100 \mathrm{~kg}$ yield removes $0.28 \mathrm{~kg}$ nitrogen, $0.11 \mathrm{~kg}$ phosphoric anhydride and $0.34 \mathrm{~kg}$ potassium oxide [57], and fertilization must be carried out considering the soil physical and chemical properties. The nutrients required by rocket plants can also be supplied through fertigation and the nutritive solution should have an EC ranging from 1500 to $2500 \mu \mathrm{S} \mathrm{cm}^{-1}$ and $\mathrm{pH}$ from 6.0 to 6.5. The relationship between $\mathrm{N}, \mathrm{P}_{2} \mathrm{O}_{5}$ and $\mathrm{K}_{2} \mathrm{O}$ changes according to the cultivation phase of application: 1.5:0.5:1.0 from sowing or transplanting to the first harvests and 2.0:0.5:1.5 in each successive interval between regrowth and harvest. Several studies $[87,88]$ have shown that in spring-summer plantings in open field, nitrogen supply should never exceed $100 \mathrm{~kg} \mathrm{ha}^{-1}$; however, when 3 to 5 harvests are planned under protected environment on a sandy soil the doses can even be doubled. Indeed, the time span between planting or regrowth and harvest is short in D. tenuifolia and, in addition, its leaves tend to accumulate large amounts of nitrate even reaching $10 \mathrm{~g} \cdot \mathrm{kg}^{-1}$ fresh weight $[89,90]$, as the nitrogen use efficiency of this species is quite low [91]. Moreover, excessive nitrogen worsens product quality during storage and, therefore, its application must be strictly avoided close to harvesting time, especially in soilless cropping. However, nitrogen availability interacts with the soil water on yield and quality produce [92], and nitrogen use efficiency is reportedly higher under 60 rather than $120 \mathrm{~kg} \cdot \mathrm{ha}^{-1}$ supply, though the latter results in $13 \%$ higher yield [86]. 
Perennial wall-rocket is adapted to harsh and arid soils, and the presence of a well-developed taproot reaching up to $40 \mathrm{~cm}$ in depth suggests limiting irrigation; in fact, excess water may worsen crop sanitary status, particularly with respect to the incidence of fungal diseases. However, it must be also considered that a good water availability is essential to ensure optimum quality of leaves, which otherwise become too fibrous and less succulent.

Adequate water availability is needed to D. tenuifolia crop in order to obtain high yield and good quality produce [7]. Indeed, water shortage reduces rocket production as a result of a concurrent decrease of leaf number per plant and leaf size, and it also affects qualitative characters, such as the antioxidant content [93].

Irrigation in "baby leaf" oriented crops is performed by the sprinkler method with $0.05-0.10$ nozzles $\mathrm{m}^{-2}$ (spaced $3 \times 3 \mathrm{~m}$ ) of 100-200 L.h $\mathrm{h}^{-1}$ flow, set over $2 \mathrm{~m}$ height in order to avoid obstructing machine running; drip irrigation $\left(2-4 \mathrm{~L} \cdot \mathrm{h}^{-1}\right)$ better fits fresh market cultivation instead. However, wet excess can result in tender leaves more prone to disease attacks, though water shortage during cultivation causes plants with stunted growth as well as dark green colour and thick leaves. Crop water consumption ranges from $35 \mathrm{~mm}$ in autumn to $48 \mathrm{~mm}$ in autumn-spring cycle, with 3 to 5 watering events [86]. Irrigation interacts with nitrogen in affecting the main yield traits of wild rocket and $100 \%$ replenishment of water consumption results in maximizing marketable yield, with the average plant weight and leaf number per plant mainly contributed to this outcome [86]. Yield water use efficiency reportedly varies from 33.0 to $37.3 \mathrm{~kg} \mathrm{~m}^{-3}$ among the different crop cycles and it is $16 \%$ higher under $120 \mathrm{~kg} \cdot \mathrm{ha}^{-1}$ nitrogen supply than with half dose application [86].

Weed infestation can be very detrimental to $D$. tenuifolia product quality, causing a costly labour to separate them from crop leaves, though perennial wall-rocket shows good competition ability. Several weeds grow within this crop, such as Stellaria media (L.) Vill. and Veronica spp. in winter, Portulaca oleracea L., Chenopodium album L., Solanum nigrum L. and Echinochloa crus-galli (L.) P. Beauv. in summer. However, environmentally friendly strategies for weed control should be preferred to herbicide use, since very few active principles are registered in all countries, not having a wide action range and high selectivity degree. Indeed, herbicide applications can be performed before planting but they need to be integrated by manual weeding [94]. Therefore, weeds should be preventively controlled by physical, agronomic and chemical means. Indeed, soil usually undergoes one of the possible disinfestation methods before planting, i.e., solarization, steam, pyrodisinfestation, fumigation. In the case of fresh market oriented produce, weed control is also achieved by growing the crops on mulched soil, though integrative manual removal is needed during cultivation.

The growth of D. tenuifolia plants in autumn-spring cycles ranges from 1.9 to 3.3 as expressed in terms of LAI and from 1.9 to $8.4 \mathrm{~g}$ as a plant mean weight [86]. Perennial wall-rocket crop cycles have quite variable duration [83], depending on various factors such as climatic conditions, crop management and phytosanitary status, and the market demand, which also determine the number of possible successive harvests.

Harvest of $D$. tenuifolia leaves is effected at the pre-inflorescence stage, 20-100 days after planting or regrowth according to cultivation period, environment and market destination [60,86,87]; after the first harvest even $4-5$ further crop cycles are achievable, depending on pedo-climatic conditions [7]. In warm periods harvest should be performed in early morning, in order to prevent leaf tissue dehydration, and maintain the cold chain using refrigerated lorries to transport the produce from fields to processing factories.

Harvesting is carried out manually for fresh market oriented crops, using a knife or sickle to which a collecting plate is applied; otherwise, "baby leaf" crops are harvested mechanically. At each harvest, the leaves must be cut $3-5 \mathrm{~cm}$ above the cotyledons to avoid damage of the vegetative apex, thus allowing for a fast and abundant regrowth. When D. tenuifolia is grown from autumn to spring, 4 to 5 cuts can be made when the leaves have reached the 10 to $15 \mathrm{~cm}$ length, whereas a few harvests can be performed in summer [88]; marketable yield ranges from 0.5 to $1.8 \mathrm{t} \cdot \mathrm{ha}^{-1}$ per each growing cycle, with total production even exceeding $60 \mathrm{t} \cdot h \mathrm{a}^{-1}$. 
After harvesting, the product is placed in plastic boxes and, for the preparation of ready-to-use salads, the leaves must be quickly refrigerated and conditioned in order to achieve a long shelf-life produce. Quality control pertains to pesticide residues, heavy metals, nitrate content and microbial contamination, referring to the official standard thresholds.

In soilless systems, a better foliage uniformity is obtained and the production can be planned by appropriately managing the most relevant environmental and technical parameters (temperature, humidity, fertilization), allowing for a substantial reduction of the occurrence of foliar diseases and weed contamination and produce clear of any foreign bodies, thus making it faster the process from washing to packaging.

\section{Diseases, Pests and Crop Protection}

By reason of the demand increase for ready-to-use vegetables and ensuing crop intensification, a higher occurrence of diseases and pests has been recorded. Not surprisingly, most reports concerning the biological adversities of $D$. tenuifolia come from Italy. However, they can represent a valid reference for other countries with similar climatic conditions where the crop has been introduced more recently.

Soil-borne fungi appear to be a widespread problem in all Italian regions, since inoculum of these pathogens may accumulate in the soil and lead to real outbursts in a few years. In Piana del Sele (Southern Italy), repeated cropping was regarded as the main contributory factor in epidemics of crown and root rot caused by Rhizoctonia solani AG-4 [95]. Diseased plants undergo either an acute (damping-off) or a chronic course, with symptoms consisting in necrotic lesions on one side of both crown and taproot, and leaf yellowing. Sclerotinia sclerotiorum (Lib.) de Bary has been also reported as an agent of crown and stem necrosis [96,97]; however, it can be easily recognized because infected tissues become rather soft and watery, and are covered with white mycelium and dark sclerotia. Unlike $R$. solani, a higher severity of this fungus is observed under conditions of low temperature and high relative humidity.

Outbursts of Fusarium wilt in plastic tunnels were recorded in Northern Italy after 3 years during which crop yield had progressively declined. Occurrence of the disease in distant farms in the same area was taken as an indication of the pathogen ability to propagate through seeds [98,99]. In this case disease symptoms consist of leaf chlorosis, reduced development, epinasty and wilting; at an advanced stage, necrosis of vascular tissues of taproot is also evident. Isolations from diseased plants yielded two different formae speciales, conglutinans and raphani, of Fusarium oxysporum [100,101]. A number of cultivars were used in tests for resistance from which it resulted that susceptibility to F. oxysporum $\mathrm{f}$. sp. raphani is widespread, and that different races of this pathogen possibly exist [102].

Seeds are also a vehicle for the diffusion of downy mildew caused by Hyaloperonospora parasitica. In Italy this fungal pathogen, possibly representing a limiting factor in cropping perennial wall-rocket, is known to commonly affect winter cruciferous crops without causing relevant damage. However, in the case of $D$. tenuifolia the protected environment may represent a favourable context for rapid spread [103]. Symptoms consist of small, irregular, dark brown speckling on the upper surface of the leaves, expanding into larger spots where fruiting structures appear in the form of a whitish mold. Infected leaves yellow suddenly and rot in the case of high infestations. Disease course may be quite deceptive, since its signs can appear when the product is on the market shelves. In fact, the pathogen develops even at low temperatures, which only prolong its incubation period, usually up to 12 days under favourable conditions [104]. Therefore, an economic threshold is often reached and control practices are recommended. White rust is another quite common foliar disease on winter cruciferous crops in temperate countries. Its agent Albugo candida is quite a heterogeneous pathogen $[105,106]$, causing local infections resulting in the appearance of white pustules on the lower surface corresponding to tan-yellow pustules at the upper surface. Tissues around the pustules become necrotic, causing leaf senescence. This species is reported to be particularly noxious in India on oil-seed crops by reason of possible systemic infections involving the inflorescence, which often occur in association with H. parasitica [107]. 
Other fungal diseases occasionally observed in Italy are powdery mildew caused by Erisyphe cichoracaearum, and Alternaria leaf spot [94]. The latter disease is mainly incited by A. japonica [108], which causes extensive foliar necrosis and can be propagated through infected seeds [109], and A. brassicicola, while some degree of resistance has been described toward other species infecting Cruciferae, such as A. brassicae and A. raphani $[110,111]$. Other foliar pathogens causing yield losses have been more recently reported from the Italian largest cropping areas in Campania. Particularly, Plectosphaerella cucumerina causes small coalescing brown-black irregular spots and leaf distortion [112], and Fusarium equiseti produces gray-brown circular spots surrounded by a violet-brown halo [113]. Again both these pathogens are possibly transmitted through seeds [114,115]. Some level of resistance has also been reported toward blackleg caused by Leptosphaeria maculans (anamorph Phoma lingam) [116,117], a pathogen of general occurrence on cruciferous crops which also causes foliar symptoms, and can spread through infected seeds.

More circumstantial concern exists for another common disease of Brassicaceae, such as clubroot caused by Plasmodiophora brassicae [118]. In this case the first visible symptoms are represented by wilting, particularly during hot-dry weather. Diseased plants are generally stunted, and the foliage may be different in colour from healthy plants. Characteristic swellings or knots are visible on roots, with taproots of young plants forming a single-clubbed root in case of severe infections. On D. tenuifolia, this disease has been reported in New Zealand [119], and Switzerland [120]; its possible incidence is to be considered in other central and northern European countries, where the pathogen is quite widespread.

Among bacterial diseases, black rot caused by Xanthomonas campestris pv. campestris is known to affect most weedy crucifers [121], including D. tenuifolia [122]. Leaves of diseased plants typically show a yellow colour at the upper surface, while the lower surface turns dark, almost black. Infection progresses along the main vein, and necrosis may even reach the stem; the pathogen spreads through the seeds and irrigation. Damage consisting of leaf spots has been ascribed to another pathovar (X. campestris pv. raphani) in a report from Florida [123].

Phytoplasmas [124] and a number of viruses, such as cucumber mosaic cucumovirus (CMV), turnip yellow mosaic tymovirus (TYMV), turnip mosaic potyvirus (TuMV) and cauliflower mosaic caulimovirus (CaMV) [94,125], are also reported to be able to infect D. tenuifolia, but no substantial damage caused by these pathogens has been reported so far. More recently, plants of D. tenuifolia showing moderate leaf yellowing symptoms were found associated with parietaria mottle ilarvirus $(\mathrm{PMoV})$ infections in Southern Italy [126]. Latent infections reported on Diplotaxis species may imply an epidemiological role by perennial wall-rocket in the spread of other viruses too, such as tomato spotted wilt tospovirus (TSWV) and pelargonium zonate spot anulavirus (PZSV) [127-129].

Plant protection strategies are on the way to adapt to the increasing diffusion of this crop. In order to overcome interspecific cross barriers and transfer disease resistance with reference to foliar diseases, somatic hybrids have been produced by using D. tenuifolia as donor and Brassica oleracea var. capitata as recipient. Within a group of 33 asymmetric hybrids regenerated, two hybrids showed resistance to Alternaria spp. (one to A. brassicicola and the other to A. brassicae), 19 showed resistance to L. maculans, 18 to $P$. brassicae, while three were resistant to TuMV [130]. A high rate of hybrids (70\%) was found with combined resistance to both $L$. maculans and P. brassicae. These results demonstrate that development of resistant hybrids by protoplast fusion, even from susceptible parent species such as D. tenuifolia and B. oleracea, discloses perspectives for enlarging the range of desirable traits, particularly concerning disease resistance.

Management of cryptogamic diseases of perennial wall-rocket should assume soil-borne pathogens as the first instance. Considering that no commercial resistant cultivars are available to effectively contrast these biological adversities, different techniques in view of accomplishing soil disinfestation at some extent can be adopted. In this respect, the use of chemicals is declining after phasing out of methyl bromide by reason that the alternative available products, such as metham sodium and dazomet, are reported not to be as effective. A rational use of certain cropping practices, 
such as rotation, fertilization and irrigation, can result in reduction of inoculum accumulation in the soil. In subtropical and temperate countries, solarization could be adopted, provided that it does not impair the farm organization and the rotation programs. The use of biological control products based on mycoparasites, such as Clonostachys rosea against F. oxysporum or $R$. solani and Paraconiothyrium minitans against $S$. sclerotiorum, could be particularly convenient when the crop is transplanted. In fact, these fungi can be supplied in advance in order to become resident in the rhizosphere, and contrast the pathogens' infection in the field. These mycoparasites could work even when disease incidence is low, considering that their antagonistic role against pathogens can target the resting structures (e.g., sclerotia of S. sclerotiorum), or affect their saprophytic development on crop residues and the organic matter [94]. Another environmentally friendly practice to be considered if adopting leaf fertilization is the use of phosphites, well-known for their ability to induce phytoalexins and ensuing plant protective effects [131]. Considering the short cycle of the crop and prevalent use as a fresh product, chemical control against downy mildew should be carried out by using products with very short intervals. In this respect copper salts are effective against the black rot and leaf spot agents [132], but their use is not suggested since stains persist on the foliage. Seed disinfection is not a routine practice; however, the definition of a protocol for their sterilization would be extremely useful, considering that several pathogens are known to propagate through them. Treatment of seeds with vinegar for $15 \mathrm{~min}$ is effective against downy mildew and is recommended in Switzerland [120].

Pest reports on D. tenuifolia generally refer to insect species common on other Brassicaceae, such as flea beetles (Phyllotreta spp.), click beetles (Agriotes spp.), aphids (Brevicoryne brassicae, Myzus persicae, Lipaphis erysimi), cabbage butterflies (Pieris spp.), and cutworms (Mamestra brassicae, Autographa gamma, Spodoptera littoralis) $[7,94]$. Other Lepidoptera known for having caused some extent of economic damage in Italy are the diamondback moth (Plutella xylostella) [133] and the cabbage webworm (Hellula undalis) [134]. Flea beetles are also indirectly injurious as vectors of TYMV and in mild climatic conditions can be particularly harmful early in spring. In fact, damage consisting of leaf erosions is caused by the adults, representing the overwintering stage, while larvae only feed on roots without being particularly noxious [135]. The milder temperatures recorded in winter in the last decades in Piana del Sele determined an unusual spread of springtails (Sminthurus viridis) [136], whose feeding habit also causes riddling and erosion of leaves that become unmarketable. In Southern Italy the occurrence of the leafminer flies Lyriomiza spp. and Chromatomyia spp. (Diptera: Agromyzidae) has been reported without serious damages, while episodic outbreaks of Scaptomyza flava (Diptera: Drosophilidae), which causes the formation of large mines affecting the entire adaxial leaf surface, have sometimes resulted in consistent economic losses [137]. In Central Italy, crop productivity has been sometimes compromised by root degradation caused by Bradysia difformis (Diptera: Sciaridae) larvae [138]. Among the herbivorous insects recorded on Diplotaxis there are some feeding on flowers, including the pollen beetle Meligethes aeneus (Coleoptera: Nitidulidae) [137], and gall midges (Diptera: Cecidomyiidae) $[139,140]$, that could potentially be harmful to seed crops. Recently, the invasive stink bug Bagrada hilaris (Hemiptera: Pentatomidae), a serious pest of cruciferous crops in the United States, has been found to feed and deteriorate wild plants of $D$. tenuifolia, that serve as an alternative host to the bugs [141]. This suggests that $B$. hilaris as well as other stink bugs feeding on cruciferous plants could become pests to perennial wall-rocket. Mite outbreaks caused by Bryobia spp. (Acari: Tetranichidae), associated with severe crop damage, have been reported in Northern and Southern Italy $[142,143]$. The eriophyid mite Metaculus diplotaxi (Acari: Eriophyoidea) is able to cause severe stunting of wild rocket plants [144], but to our knowledge this species is not known as a crop pest yet.

Besides representing a direct economic loss, the presence of damaged leaves requires a quite onerous choice operation and can make the harvesting uneconomical. Consequently, most of the pests have very low economic thresholds, and their control is mainly based on insecticide applications. The use of pesticides on perennial wall-rocket is quite problematic due to the very short interval between subsequent harvestings, and persistent chemicals cannot be used. Therefore pyrethroids (e.g., deltamethrin, cypermethrin), that have proved to be very efficacious against aphids, flea beetles, 
springtails and cutworms, are frequently employed. However, their indiscriminate use can be deleterious, since it may favour the proliferation of secondary pests such as mites and leafminers, whose outbreaks have already been recorded in several Italian areas [137,142,143]. Recently, at least for European growers, the choice of active ingredients authorized against $D$. tenuifolia pests has been enlarged, and several chemical classes with different modes of action can be used for the integrated pest management of this crop. Most of these insecticides are characterized by a short security interval (3-7 day). Consequently, in order to avoid the selection of resistant pest populations, it is important to adopt insecticide management protocols with alternation of active ingredients characterized by a different mechanism of activity. Chemical insecticides can be integrated by natural products such as azadirachtin, which has proved to be effective against aphids and Lepidoptera larvae and has shown a substantial anti-feedant effect on flea beetles [135]. The impact of chemical compounds and the accumulation of residues in the leaves may be reduced by using Bacillus thuringiensis based products that are effective against Lepidoptera larvae, and selective to their natural enemies, such as the parasitoids Angitia tibialis and Apanteles spp., whose role as biological control agents may contribute to the management of P. xylostella [135]. In addition, products based on baculoviruses, such as Helicoverpa armigera nucleopolyhedrovirus and Spodoptera littoralis nucleopolyhedrovirus, could be employed to control their specific hosts [145]. Slugs (e.g., Deroceras reticulatum, Arion spp.) are also occasionally injurious and should be particularly considered in subtropical countries for their ability to transmit a number of human parasitic Trematodes (e.g., Fasciola hepatica). Baits treated with methaldeyde are usually effective against these pests [94].

\section{Industrial Processing}

After harvesting, leaves of perennial wall-rocket undergo a leakage of cell juices providing immediate support for microbial growth; moreover, many enzyme systems are activated, which are responsible for modifications in flavour and consistency, and loss of nutritional properties. In fact, content in vitamin $\mathrm{C}$ rapidly falls [146], and as a result of increased respiratory activity, $\mathrm{CO}_{2}$ develops up to $42-113 \mathrm{~mL} \mathrm{~kg}^{-1} \mathrm{~h}^{-1}$ at $0-5^{\circ} \mathrm{C}$; although ethylene is produced in low amounts (less than $0.1 \mathrm{~mL} \mathrm{~kg}^{-1} \mathrm{~h}^{-1}$ ), leaves are highly sensitive and readily suffer chlorophyll degradation and yellowing [147]. Additional volatile organic compounds are released and contribute to the overall qualitative degradation; the list of such products includes acetone, acetaldehyde, methanol, methanethiol, ethanol, methyl acetate, ethyl acetate, methyl propionate, methyl and ethyl 3-methylbutanoate, methyl isothiocyanate, pentane, hexane, heptane, octane, hexanal, dimethyl sulfoxide, dimethyl sulphide/disulfide/trisulfide, carbonyl sulfide/disulfide, nitromethane, 3-methylfuran and 2-ethylfuran [148,149]. The glucosinolate content is also partially altered [146,150]. A variation in respiration rate depending on season and harvest time has been also documented, which is related to drymatter content and occurs as a consequence of even minor temperature fluctuation [151]. Therefore, storage at low temperatures $\left(\leq 5^{\circ} \mathrm{C}\right)$ must be done immediately after harvesting, any delay resulting in shelf life reduction [152]. Due to $D$. tenuifolia resistance to coldness, temperatures of $0-2{ }^{\circ} \mathrm{C}$ can be born for periods up to 10 days [147].

As for other leaf vegetables, there is a great concern for possible microbial contamination. Microbiological analyses of the product must guarantee the absence of human pathogenic bacteria, such as Salmonella spp., Listeria monocytogenes, Yersinia enterocolitica, and the presence of Staphylococcus aureus, Escherichia coli and other coliforms under the limit of $100 \mathrm{cfu}^{-1}[153,154]$. Salmonella typhimurium is particularly hazardous to this crop, considering its documented ability to internalize in the intercellular spaces of the spongy parenchyma of rocket leaves, thereby possibly escaping disinfection [155]. Aeromonas spp. have also been found on $D$. tenuifolia leaves [156]. Therefore a greater attention must be paid to the quality of water for both irrigation and washing. Sanitization can be operated by accurate washing with cold tap water supplemented with a disinfectant. Chlorine products are prevalently used [157], but good effects have also been obtained by treating with lactic acid $\left(20 \mathrm{~mL} \mathrm{~L}^{-1}\right)$ and peroxyacetic acid $\left(300 \mathrm{mg} \mathrm{L}^{-1}\right)$, which experimentally inhibited the microbial growth throughout the shelf life [158]. 
As introduced above, the major aim of the technology of the fourth generation of vegetables is to preserve the visual quality of the product and its organoleptic properties for a prolonged period, i.e., a week at least. Appropriate films are used for packaging, which show differential permeability toward oxygen and carbon dioxide, based on reduction of ethylene biosynthesis and chlorophyll loss occurring at low $\mathrm{O}_{2}$ or high $\mathrm{CO}_{2}$ levels [159]. A controlled atmosphere may also be artificially created in the plastic bags with even lower $\mathrm{O}_{2}$ and higher $\mathrm{CO}_{2}$ concentrations; however, weight loss is inevitable to a certain extent, and it has been documented even at levels of $3 \% \mathrm{O}_{2}$ and $15 \% \mathrm{CO}_{2}$ after 10 days storage [147]. Experimental data concerning modifications in the nutritional value are indicative of a reduction in ascorbic acid, flavonoid and glucosinolate content under a low $\mathrm{O}_{2}(1-3 \mathrm{kPa})$ and high $\mathrm{CO}_{2}(11-13 \mathrm{kPa})$ atmosphere [158]; by contrast, the total flavonoid content is unaffected or even increases, under a controlled atmosphere of $5 \mathrm{kPa} \mathrm{O}$ and $10 \mathrm{kPa} \mathrm{CO}_{2}$ [160]. Therefore, further studies are necessary for a more conclusive assessment of the efficacy of D. tenuifolia leaves stored under a controlled atmosphere, and the most appropriate levels of $\mathrm{O}_{2}$ and $\mathrm{CO}_{2}$.

\section{Conclusions}

D. tenuifolia was converted from a wild species to an interesting crop about twenty-five years ago, thus increasing more and more in terms of farm diffusion. Notably, it has been drawing attention from vegetable operators due to its climatic resilience, successful yield performances, and profitability. This produce impact on consumers is connected to its pungent taste depending on the presence of valuable bioactive compounds, such as glucosinolates, which further characterize the excellent nutraceutical properties deriving from the high content of antioxidants. The mentioned features have enabled spread of perennial wall-rocket in crop systems even outside the native Mediterranean area, introducing it as an interesting option for vegetable growers worldwide.

Author Contributions: G.C. and R.N. conceived the paper and organized the text; G.P. and M.G. completed Section 6; G.C. completed Sections 4, 5 and 7; R.N. completed the introduction and Sections 2 and 3.

Conflicts of Interest: The authors declare no conflict of interest.

\section{References}

1. Parsons, W.T.; Cuthbertson, E.G. Noxious Weeds of Australia; Inkata Press: Melbourne, Australia, 1992; pp. 342-344.

2. Bonasia, A.; Lazzizera, C.; Elia, A.; Conversa, G. Nutritional, biophysical and physiological characteristics of wild rocket genotypes as affected by soilless cultivation system, salinity level of nutrient solution and growing period. Front. Plant Sci. 2017, 8. [CrossRef] [PubMed]

3. Warwick, S.I.; Sauder, C.A. Phylogeny of tribe Brassiceae (Brassicaceae) based on chloroplast restriction site polymorphisms and nuclear ribosomal internal transcribed spacer and chloroplast trnL intron sequences. Can. J. Bot. 2005, 83, 467-483. [CrossRef]

4. Martínez-Laborde, J.B. A brief account on the genus Diplotaxis. In Rocket: A Mediterranean Crop for the World; Padulosi, S., Pignone, D., Eds.; International Plant Genetic Resources Institute: Rome, Italy, 1996; pp. 13-22.

5. Sobrino Vesperinas, E. Posición taxonómica de Diplotaxis cretacea Kotov (Cruciferae). Anales Jard. Bot. Madrid 1996, 54, 182-188.

6. Martín, J.P.; Sánchez-Yélamo, M.D. Genetic relationships among species of the genus Diplotaxis (Brassicaceae) using inter-simple sequence repeat markers. Theor. Appl. Genet. 2000, 101, 1234-1241. [CrossRef]

7. Bianco, V.V. Rocket, an ancient underutilized vegetable crop and its potential. In Rocket Genetic Resource Network; Padulosi, S., Ed.; International Plant Genetic Resources Institute: Rome, Italy, 1995; pp. 35-57.

8. Eschmann-Grupe, G.; Neuffer, B.; Hurka, H. Extent and structure of genetic variation in two colonising Diplotaxis species (Brassicaceae) with contrasting breeding. Plant Syst. Evol. 2004, 244, 31-43. [CrossRef]

9. Eschmann-Grupe, G.; Hurka, H.; Neuffer, B. Species relationships within Diplotaxis (Brassicaceae) and the phylogenetic origin of D. muralis. Plant Syst. Evol. 2004, 243, 13-29. [CrossRef]

10. Koul, K.K.; Nagpal, R.; Raina, S.N. Seed coat microsculpturing in Brassica and allied genera (Subtribes Brassicinae, Raphaninae, Moricandiinae). Ann. Bot. 2000, 86, 385-397. [CrossRef] 
11. Ueno, O.; Wada, Y.; Wakai, M.; Bang, S.W. Evidence from photosynthetic characteristics for the hybrid origin of Diplotaxis muralis from a C3-C4 intermediate and a C3 species. Plant Biol. 2006, 8, 253-259. [CrossRef] [PubMed]

12. Apel, P.; Hillmer, S.; Pfeffer, M.; Muehle, K. Carbon metabolism type of Diplotaxis tenuifolia (L.) D.C. (Brassicaceae). Photosynthetica 1996, 32, 237-243.

13. Pignone, D. Present status of rocket genetic resources and conservation activities. In Rocket: A Mediterranean Crop for the World. Report of a Workshop, Legnaro (Italy) 13-14 December 1996; Padulosi, S., Pignone, D., Eds.; International Plant Genetic Resources Institute: Rome, Italy, 1996; pp. 2-12.

14. De Vos, A.C.; Broekman, R.; de Almeida Guerra, C.C.; van Rijsselberghe, M.; Rozema, J. Developing and testing new halophyte crops: A case study of salt tolerance of two species of the Brassicaceae, Diplotaxis tenuifolia and Cochlearia officinalis. Environ. Exp. Bot. 2013, 92, 154-164. [CrossRef]

15. Choi, E.-Y.; McNeill, A.; Coventry, D.; Stangoulis, J. Whole plant response of crop and weed species to high subsoil boron. Aust. J. Agric. Res. 2006, 57, 761-770. [CrossRef]

16. Hall, M.K.D.; Jobling, J.J.; Rogers, G.S. Factors affecting growth of perennial wall rocket and annual garden rocket. Int. J. Veg. Sci. 2012, 18, 393-411. [CrossRef]

17. Erice, G.; Sanz-Sáez, A.; Aranjuelo, I.; Irigoyen, J.J.; Aguirreolea, J.; Avice, J.-C.; Sánchez-Díaz, M. Photosynthesis, $\mathrm{N}_{2}$ fixation and taproot reserves during the cutting regrowth cycle of alfalfa under elevated $\mathrm{CO}_{2}$ and temperature. J. Plant Physiol. 2011, 168, 2007-2014. [CrossRef] [PubMed]

18. Hurka, H.; Bleeker, W.; Neuffer, B. Evolutionary processes associated with biological invasions in the Brassicaceae. Biol. Invasions 2003, 5, 281-292. [CrossRef]

19. Giordano, S.; Molinaro, A.; Spagnuolo, V.; Muscariello, L.; Ferrara, R.; Cennamo, G.; Aliotta, G. In vitro allelopathic properties of wild rocket (Diplotaxis tenuifolia DC) extract and of its potential allelochemical S-glucopyranosyl thiohydroximate. J. Plant-Microbe Interact. 2005, 1, 51-60. [CrossRef]

20. Caso, O. Fisiología de la regeneración de Diplotaxis tenuifolia (L.) D.C. B. Soc. Argent. Bot. 1972, 14, $335-346$.

21. Ziller, S.R.; Reaser, J.K.; Neville, L.E.; Brandt, K. Invasive Alien Species in South America: National Reports and Directory of Resources; Global Invasive Species Programme: Cape Town, South Africa, 2005.

22. Brown, A. Ballast plants in New York City and its vicinity. Bull. Torrey Bot. Club 1879, 6, 353-360. [CrossRef]

23. Rieger, M.A.; Preston, C.; Powles, S.B. Risks of gene flow from transgenic herbicide resistant canola (Brassica napus) to weedy relatives in southern Australia. Aust. J. Agric. Res. 1999, 50, 115-128. [CrossRef]

24. Siemens, J. Interspecific hybridisation between wild relatives and Brassica napus to introduce new resistance traits into the oilseed rape gene pool. Czech J. Genet. Plant 2002, 38, 155-157. [CrossRef]

25. Ozturk, M.; Sakcali, S.; Celik, A.A. Biomonitor of heavy metals on ruderal habitats in TurkeyDiplotaxis tenuifolia (L.) D.C. Sains Malays. 2013, 42, 1371-1376.

26. Delaveau, P.; Paris, R. Sur la composition chimique de l'essence de Diplotaxis tenuifolia (L.) D.C. Ann. Pharm. Fr. 1958, 16, 81-86. [PubMed]

27. Pasini, F.; Verardo, V.; Cerretani, L.; Caboni, M.F.; D'Antuono, L.F. Rocket salad (Diplotaxis and Eruca spp.) sensory analysis and relation with glucosinolate and phenolic content. J. Sci. Food Agric. 2011, 91, 2858-2864. [CrossRef] [PubMed]

28. D'Antuono, L.F.; Elementi, S.; Neri, R. Exploring new potential health-promoting vegetables: Glucosinolates and sensory attributes of rocket salads and related Diplotaxis and Eruca species. J. Sci. Food Agric. 2009, 89, 713-722. [CrossRef]

29. Larher, F.; Hamelin, J. 5-Dimethylsulfoniopentanoic acid from Diplotaxis tenuifolia. Phytochemistry 1979, 18, 1396-1397. [CrossRef]

30. Hanson, A.D.; Huang, Z.H.; Gage, D.A. Evidence that the putative compatible solute 5-dimethylsulfoniopentanoate is an extraction artefact. Plant Physiol. 1993, 101, 1391-1393. [CrossRef] [PubMed]

31. Fahey, J.W.; Zalemann, A.T.; Talalay, P. The chemical diversity and distribution of glucosinolates and isothiocyanates among plants. Phytochemistry 2001, 56, 5-51. [CrossRef]

32. Bell, L.; Wagstaff, C. Glucosinolates, myrosinase hydrolysis products, and flavonols found in rocket (Eruca sativa and Diplotaxis tenuifolia). J. Agric. Food Chem. 2014, 62, 4481-4492. [CrossRef] [PubMed]

33. Deng, Q.; Zinoviadou, K.G.; Galanakis, C.M.; Orlien, V.; Grimi, N.; Vorobiev, E.; Lebovka, N.; Barba, F.J. The effects of conventional and non-conventional processing on glucosinolates and its derived forms, isothiocyanates: Extraction, degradation, and applications. Food Eng. Rev. 2015, 7, 357-381. [CrossRef] 
34. Omirou, M.; Papastylianou, I.; Iori, R.; Papastephanou, C.; Papadopoulou, K.K.; Ehaliotis, C.; Karpouzas, D.G. Microwave-assisted extraction of glucosinolates from Eruca sativa seeds and soil: Comparison with existing methods. Phytochem. Anal. 2009, 20, 214-220. [CrossRef] [PubMed]

35. Pedras, M.S.C.; Yaya, E.E. Tenualexin, other phytoalexins and indole glucosinolates from wild cruciferous species. Chem. Biodivers. 2014, 11, 910-918. [CrossRef] [PubMed]

36. D'Antuono, L.F.; Elementi, S.; Neri, R. Glucosinolates in Diplotaxis and Eruca leaves: Diversity, taxonomic relations and applied aspects. Phytochemistry 2008, 69, 187-199. [CrossRef] [PubMed]

37. Nordmark, L.; Gertsson, U.; Olsson, K.; Olsson, M.E. Content of bioactive compounds in baby-leaves as affected by season and growth stage at harvest. In Proceedings of the III International Symposium on Human Health Effects of Fruits and Vegetables-FAVHEALTH, Avignon, France, 18-21 October 2009; Volume 1040, pp. 201-206.

38. Bennett, R.N.; Rosa, E.A.; Mellon, F.A.; Kroon, P.A. Ontogenic profiling of glucosinolates, flavonoids, and other secondary metabolites in Eruca sativa (salad rocket), Diplotaxis erucoides (wall rocket), Diplotaxis tenuifolia (wild rocket), and Bunias orientalis (Turkish rocket). J. Agric. Food Chem. 2006, 54, 4005-4015. [CrossRef] [PubMed]

39. Pasini, F.; Verardo, V.; Caboni, M.F.; D'Antuono, L.F. Determination of glucosinolates and phenolic compounds in rocket salad by HPLC-DAD-MS: Evaluation of Eruca sativa Mill. and Diplotaxis tenuifolia L. genetic resources. Food Chem. 2012, 133, 1025-1033. [CrossRef]

40. Bell, L.; Oruna-Concha, M.J.; Wagstaff, C. Identification and quantification of glucosinolate and flavonol compounds in rocket salad (Eruca sativa, Eruca vesicaria and Diplotaxis tenuifolia) by LC-MS: Highlighting the potential for improving nutritional value of rocket crops. Food Chem. 2015, 172, 852-861. [CrossRef] [PubMed]

41. Chun, J.H.; Arasu, M.V.; Lim, Y.P.; Kim, S.J. Variation of major glucosinolates in different varieties and lines of rocket salad. Hortic. Environ. Biotechnol. 2013, 54, 206-213. [CrossRef]

42. Kovacic, M.; Veberic, R.; Ugrinovic, K.; Jakše, M. Glucosinolate analysis of wild rocket [Diplotaxis tenuifolia (L.) D.C.] from different Slovenian regions cultivated on two growing systems. Eur. J. Hortic. Sci. 2015, 80, 199-207. [CrossRef]

43. Bennett, R.N.; Carvalho, R.; Mellon, F.A.; Eagles, J.; Rosa, E.A. Identification and quantification of glucosinolates in sprouts derived from seeds of wild Eruca sativa L. (salad rocket) and Diplotaxis tenuifolia L. (wild rocket) from diverse geographical locations. J. Agric. Food Chem. 2007, 55, 67-74. [CrossRef] [PubMed]

44. Zhang, Y.; Talalay, P.; Cho, C.G.; Posner, G.H. A major inducer of anticarcinogenic protective enzymes from broccoli: Isolation and elucidation of structure. Proc. Natl. Acad. Sci. USA 1992, 89, 2399-2403. [CrossRef] [PubMed]

45. Iori, R.; Bernardi, R.; Gueyrard, D.; Rollin, P.; Palmieri, S. Formation of glucoraphanin by chemoselective oxidation of natural glucoerucin: A chemoenzymatic route to sulforaphane. Bioorg. Med. Chem. Lett. 1999, 9, 1047-1048. [CrossRef]

46. O'Hare, T.J.; Wong, L.S.; Irving, D.E. Asian and western horticultural species of the Brassica family with anti-cancer potential. Acta Hortic. 2005, 694, 457-462. [CrossRef]

47. Cho, E.J.; Shin, J.S.; Chung, K.S.; Lee, Y.S.; Cho, Y.W.; Baek, N.I.; Chung, H.-G.; Lee, K.T. Arvelexin inhibits colonic inflammation by suppression of NF-kB activation in dextran sulfate sodium-induced mice and TNF- $\alpha$-induced colonic epithelial cells. J. Agric. Food Chem. 2012, 60, 7398-7407. [CrossRef] [PubMed]

48. Nitz, G.M.; Schnitzler, W.H. Variation der glucosinolatgehalte bei den rucolaarten Eruca sativa und Diplotaxis tenuifolia in abhängigkeit des ernteschnittes. J. Appl. Bot. 2002, 76, 82-86.

49. Kirkegaard, J.A.; Sarwar, M. Biofumigation potential of brassicas. Plant Soil 1998, 201, 71-89. [CrossRef]

50. Lu, P.; Gilardi, G.; Gullino, M.L.; Garibaldi, A. Biofumigation with Brassica plants and its effect on the inoculum potential of Fusarium yellows of Brassica crops. Eur. J. Plant Pathol. 2010, 126, 387-402. [CrossRef]

51. Ntalli, N.; Caboni, P. A review of isothiocyanates biofumigation activity on plant parasitic nematodes. Phytochem. Rev. 2017, 16, 827-834. [CrossRef]

52. Yulianti, T.; Sivasithamparam, K.; Turner, D.W. Response of different forms of propagules of Rhizoctonia solani AG2-1 (ZG5) exposed to the volatiles produced in soil amended with green manures. Ann. Appl. Biol. 2006, 148, 105-111. [CrossRef] 
53. Yulianti, T.; Sivasithamparam, K.; Turner, D.W. Saprophytic and pathogenic behaviour of R. solani AG2-1 (ZG-5) in a soil amended with Diplotaxis tenuifolia or Brassica nigra manures and incubated at different temperatures and soil water content. Plant Soil 2007, 294, 277-289. [CrossRef]

54. Klein, E.; Katan, J.; Gamliel, A. Soil suppressiveness to Fusarium disease following organic amendments and solarization. Plant Dis. 2011, 95, 1116-1123. [CrossRef]

55. Klein, E.; Katan, J.; Gamliel, A. Combining residues of herb crops with soil heating for control of soilborne pathogens in a controlled laboratory system. Crop Prot. 2011, 30, 368-374. [CrossRef]

56. Klein, E.; Katan, J.; Gamliel, A. Soil suppressiveness to Meloidogyne javanica as induced by organic amendments and solarization in greenhouse crops. Crop Prot. 2012, 39, 26-32. [CrossRef]

57. Pimpini, F.; Giannini, M.; Lazzarin, R. Ortaggi da Foglia e da Taglio; Veneto Agricoltura: Venezia, Italy, 2005; p. 118.

58. Conforti, F.; Perri, V.; Menichini, F.; Marrelli, M.; Uzunov, D.; Statti, G.A.; Menichini, F. Wild Mediterranean dietary plants as inhibitors of pancreatic lipase. Phytother. Res. 2012, 26, 600-604. [CrossRef] [PubMed]

59. Bruno, S.; Amico, A.; Stefanizzi, L. Vitamin C content of edible and medicinal plants of the Apulian region. Boll. Soc. Ital. Biol. Sper. 1980, 56, 2067-2070. [PubMed]

60. Martínez-Sánchez, A.; Gil-Izquierdo, A.; Gil, M.I.; Ferreres, F. A comparative study of flavonoid compounds, vitamin C, and antioxidant properties of baby leaf Brassicaceae species. J. Agric. Food Chem. 2008, 56, 2330-2340. [CrossRef] [PubMed]

61. National Research Council (US). Recommended Dietary Allowances, 10th ed.; National Academies Press: Washington, DC, USA, 1989; p. 285.

62. Žnidarèiè, D.; Ban, D.; Šircelj, H. Carotenoid and chlorophyll composition of commonly consumed leafy vegetables in Mediterranean countries. Food Chem. 2011, 129, 1164-1168. [CrossRef] [PubMed]

63. Salvatore, S.; Pellegrini, N.; Brenna, O.V.; Del Rio, D.; Frasca, G.; Brighenti, F.; Tumino, R. Antioxidant characterization of some Sicilian edible wild greens. J. Agric. Food Chem. 2005, 53, 9465-9471. [CrossRef] [PubMed]

64. Durazzo, A.; Azzini, E.; Lazzè, M.C.; Raguzzini, A.; Pizzala, R.; Maiani, G. Italian wild rocket [Diplotaxis tenuifolia (L.) D.C.]: Influence of agricultural practices on antioxidant molecules and on cytotoxicity and antiproliferative effects. Agriculture 2013, 3, 285-298. [CrossRef]

65. Maldoni, B.E.; Haurie, H.M.; Bartolome, E.R. Chemical study of weeds in the Buenos Aires province of Argentina. I. Diplotaxis tenuifolia. Anal. Assoc. Quim. Argent. 1988, 76, 237-240.

66. Sánchez-Yélamo, M.D. A chemosystematic survey of flavonoids in the Brassicinae: Diplotaxis. Bot. J. Linn. Soc. 1994, 115, 9-18. [CrossRef]

67. Heimler, D.; Isolani, L.; Vignolini, P.; Tombelli, S.; Romani, A. Polyphenol content and antioxidative activity in some species of freshly consumed salads. J. Agric. Food Chem. 2007, 55, 1724-1729. [CrossRef] [PubMed]

68. Martínez-Sánchez, A.; Llorach, R.; Gil, M.I.; Ferreres, F. Identification of new flavonoid glycosides and flavonoid profiles to characterize rocket leafy salads (Eruca vesicaria and Diplotaxis tenuifolia). J. Agric. Food Chem. 2007, 55, 1356-1363. [CrossRef] [PubMed]

69. Truchado, P.; Tourn, E.; Gallez, L.M.; Moreno, D.A.; Ferreres, F.; Tomás-Barberán, F.A. Identification of botanical biomarkers in Argentinean Diplotaxis honeys: Flavonoids and glucosinolates. J. Agric. Food Chem. 2010, 58, 12678-12685. [CrossRef] [PubMed]

70. Treutter, D. Significance of flavonoids in plant resistance and enhancement of their biosynthesis. Plant Biol. 2005, 7, 581-591. [CrossRef] [PubMed]

71. Di Venere, D.; Calabrese, N.; Linsalata, V.; Cardinali, A.; Bianco, V.V. Influence of sowing time on phenolic composition of rocket. Acta Hortic. 2000, 533, 343-349. [CrossRef]

72. Bouchereau, A.; Hamelin, J.; Lamour, I.; Renard, M.; Larher, F. Distribution of sinapine and related compounds in seeds of Brassica and allied genera. Phytochemistry 1991, 30, 1873-1881. [CrossRef]

73. Brock, A.; Herzfeld, T.; Paschke, R.; Koch, M.; Draeger, B. Brassicaceae contain nortropane alkaloids. Phytochemistry 2006, 67, 2050-2057. [CrossRef] [PubMed]

74. Rodriguez, S.A.; Vela Gurovic, M.S.; Mulet, M.C.; Murray, A.P. Diplotaxis tenuifolia (L.) D.C., a source of a potentially antifungal essential oil containing nitrile. Biochem. Syst. Ecol. 2006, 34, 353-355. [CrossRef]

75. Dolya, V.S.; Koreshchuk, K.E.; Fursa, N.S.; Golodner, D.N.; Kaminskii, N.A. Oils from three representatives of Cruciferae family. Khimiya Prirodnykh Soedinenii 1972, 3, 386-387. 
76. Agullo, E.; Maldoni, B.E.; Rodriguez, M.S. Diplotaxis tenuifolia (wallrocket) seed. Extraction of the crude oil. Anal. Assoc. Quim. Argent. 1987, 75, 105-110.

77. Tonguc, M.; Erbas, S. Evaluation of fatty acid compositions and some seed characters of common wild plant species of Turkey. Turk. J. Agric. For. 2012, 36, 673-679.

78. Shoaib, A.; Saeed, G.; Ahmad, S. Antimicrobial activity and chemical analysis of some edible oils (Clove, Kalonji and Taramira). Afr. J. Biotechnol. 2014, 13, 4347-4354.

79. De Feo, D.; Senatore, F.; De Feo, V. Medicinal plants and phytotherapy in the Amalfitan coast; Salerno province, Campania, southern Italy. J. Ethnopharmacol. 1993, 39, 39-51. [CrossRef]

80. De Feo, V.; Aquino, R.; Menghini, A.; Ramundo, E.; Senatore, F. Traditional phytotherapy in the peninsula Sorrentina, Campania, Southern Italy. J. Ethnopharmacol. 1992, 36, 113-125. [CrossRef]

81. Pieroni, A.; Quavec, C.L.; Santoro, R.F. Folk pharmaceutical knowledge in the territory of the Dolomiti Lucane, inland southern Italy. J. Ethnopharmacol. 2004, 95, 373-384. [CrossRef] [PubMed]

82. Caudron, D. Un mucolytique d'origine végétale Diplotaxis tenuifolia. Phytothérapie Européenne 2005, 25, 26-28.

83. Nicola, S.; Hoeberechts, J.; Fontana, E. Comparison between traditional and soilless culture systems to produce rocket (Eruca sativa) with low nitrate content. Acta Hortic. 2005, 697, 549-555. [CrossRef]

84. Cavarianni, R.L.; Cecílio Filho, A.B.; Cazetta, J.O.; May, A.; Corradi, M.M. Nutrient contents and production of rocket as affected by nitrogen concentrations in the nutritive solution. Sci. Agric. 2008, 65, 652-658. [CrossRef]

85. Hall, M.; Jobling, J.; Rogers, G. Some perspectives on rocket as a vegetable crop: A review. Veg. Crops Res. Bull. 2012, 76, 21-41. [CrossRef]

86. Schiattone, M.I.; Viggiani, R.; Di Venere, D.; Sergio, L.; Cantore, V.; Todorovic, M.; Perniola, M.; Candido, V. Impact of irrigation regime and nitrogen rate on yield, quality and water use efficiency of wild rocket under greenhouse conditions. Sci. Hortic. 2018, 229, 182-192. [CrossRef]

87. Pimpini, F.; Enzo, M. Present status and prospects for rocket cultivation in the Veneto region. In Rocket: A Mediterranean Crop for the World. Report of a Workshop, Legnaro (Italy), 13-14 December 1996; Padulosi, S., Pignone, D., Eds.; International Plant Genetic Resources Institute: Rome, Italy, 1996; pp. 51-66.

88. Bianco, V.V.; Boari, F. Up-to-date developments on wild rocket cultivation. In Rocket: A Mediterranean Crop for the World. Report of a Workshop, Legnaro (Italy) 13-14 December 1996; Padulosi, S., Pignone, D., Eds.; International Plant Genetic Resources Institute: Rome, Italy, 1996; pp. 41-49.

89. Santamaria, P.; Gonnella, M.; Elia, A.; Parente, A.; Serio, F. Ways of reducing rocket salad nitrate content. Acta Hortic. 2001, 548, 529-536. [CrossRef]

90. Caruso, G.; Conti, S.; La Rocca, G. Influence of crop cycle and nitrogen fertilizer form on yield and nitrate content in different species of vegetables. Adv. Hortic. Sci. 2011, 25, 81-89.

91. Santamaria, P.; Elia, A.; Serio, F. Effect of solution nitrogen concentration on yield, leaf element content, and water and nitrogen use efficiency of three hydroponically-grown rocket salad genotypes. J. Plant Nutr. 2002, 25, 245-258. [CrossRef]

92. Hu, Y.C.; Schmidhalter, U. Drought and salinity: A comparison of their effects on mineral nutrition of plants. J. Plant Nutr. Soil Sci. 2005, 168, 541-549. [CrossRef]

93. Stefanelli, D.; Goodwin, I.; Jones, R. Minimal nitrogen and water use in horticulture: Effects on quality and content of selected nutrients. Food Res. Int. 2010, 43, 1833-1843. [CrossRef]

94. Nicoletti, R.; Raimo, F.; Miccio, G.; Carella, A. Avversità biologiche della rucola selvatica (Diplotaxis tenuifolia). In Atti del Progetto 'Analisi e Valutazione di Ordinamenti Colturali Alternativi Nelle Aree a Riconversione del Tabacco'; Consiglio per la Ricerca e la Sperimentazione in Agricoltura: Rome, Italy, 2007; pp. 298-304.

95. Nicoletti, R.; Raimo, F.; Miccio, G. First report of Rhizoctonia solani on Diplotaxis tenuifolia in Italy. Plant Pathol. 2004, 53, 811. [CrossRef]

96. Garibaldi, A.; Minuto, A.; Gullino, M.L. First report of Sclerotinia stem rot and watery soft rot caused by Sclerotinia sclerotiorum on sand rocket (Diplotaxis tenuifolia) in Italy. Plant Dis. 2005, 89, 1241. [CrossRef]

97. Minuto, A.; Pensa, P.; Rapa, B.; Garibaldi, A. Sclerotinia sclerotiorum (Lib.) de Bary nuovo agente di alterazione basale e fogliare della Diplotaxis tenuifolia (L.) D.C. Inf. Fitopatol. 2005, 55, 43-45.

98. Garibaldi, A.; Gilardi, G.; Gullino, M.L. Una tracheofusariosi su Eruca sativa e Diplotaxis sp. osservata per la prima volta in Europa. Inf. Fitopatol. 2002, 52, 57-59.

99. Garibaldi, A.; Gilardi, G.; Gullino, M.L. First report of Fusarium oxysporum on Eruca vesicaria and Diplotaxis spp. in Europe. Plant Dis. 2003, 87, 201. [CrossRef] 
100. Garibaldi, A.; Gilardi, G.; Gullino, M.L. Evidence for an expanded host range of Fusarium oxysporum $\mathrm{f}$. sp. raphani. Phytoparasitica 2006, 34, 115-121. [CrossRef]

101. Catti, A.; Pasquali, M.; Ghiringhelli, D.; Garibaldi, A.; Gullino, M.L. Analysis of vegetative compatibility groups of Fusarium oxysporum from Eruca vesicaria and Diplotaxis tenuifolia. J. Phytopathol. 2007, 155, 61-64. [CrossRef]

102. Gilardi, G.; Chen, G.; Garibaldi, A.; Zhiping, C.; Gullino, M.L. Resistance of different rocket cultivars to wilt caused by strains of Fusarium oxysporum under artificial inoculation conditions. J. Plant Pathol. 2007, 89, 113-117.

103. Minuto, G.; Pensa, P.; Rapa, B.; Minuto, A.; Garibaldi, A. La peronospora della rucola selvatica [Diplotaxis tenuifolia (L.) D.C.] in Italia. Inf. Fitopatol. 2004, 54, 57-60.

104. Garibaldi, A.; Minuto, A.; Gullino, M.L. First report of Peronospora parasitica on wild rocket (Diplotaxis tenuifolia) in Italy. Plant Dis. 2004, 88, 1381. [CrossRef]

105. Choi, Y.-J.; Hong, S.-B.; Shin, H.-D. Genetic diversity within the Albugo candida complex (Peronosporales, Oomycota) inferred from phylogenetic analysis of ITS rDNA and COX2 mtDNA sequences. Mol. Phylogenet. Evol. 2006, 40, 400-409. [CrossRef] [PubMed]

106. Ploch, S.; Choi, Y.J.; Rost, C.; Shin, H.D.; Schilling, E.; Thines, M. Evolution of diversity in Albugo is driven by high host specificity and multiple speciation events on closely related Brassicaceae. Mol. Phylogenet. Evol. 2010, 57, 812-820. [CrossRef] [PubMed]

107. Gupta, K.; Prem, D.; Agnihotri, A. Role of biotechnology for incorporating white rust resistance in Brassica species. In Plant Biotechnology and Molecular Markers; Srivastava, P.S., Narula, A., Srivastava, S., Eds.; Kluwer Academic Publishers: Doordrecht, The Netherlands, 2004; pp. 156-168.

108. Garibaldi, A.; Gilardi, G.; Bertoldo, C.; Gullino, M.L. First report of leaf spot of wild (Diplotaxis tenuifolia) and cultivated (Eruca vesicaria) rocket caused by Alternaria japonica in Italy. Plant Dis. 2011, 95, 1316. [CrossRef]

109. Gilardi, G.; Demarchi, S.; Ortu, G.; Gullino, M.L.; Garibaldi, A. Occurrence of Alternaria japonica on seeds of wild and cultivated rocket. J. Phytopathol. 2015, 163, 419-422. [CrossRef]

110. Klewer, A.; Mewes, S.; Mai, J.; Sacristán, M.D. Alternaria-resistenz in interspezifischen hybriden und deren rückkreuzungsnachkommenschaften im tribus Brassiceae. Vortr. Pflanzenschutzforschung-Zücht 2002, 54, 505-508.

111. Sharma, G.; Dinesh Kumar, V.; Haque, A.; Bhat, S.R.; Prakash, S.; Chopra, V.L. Brassica coenospecies: A rich reservoir for genetic resistance to leaf spot caused by Alternaria brassicae. Euphytica 2002, 125, 411-417. [CrossRef]

112. Garibaldi, A.; Gilardi, G.; Ortu, G.; Gullino, M.L. First report of Plectosphaerella cucumerina on greenhouse cultured wild rocket (Diplotaxis tenuifolia) in Italy. Plant Dis. 2012, 96, 1825. [CrossRef]

113. Garibaldi, A.; Gilardi, G.; Ortu, G.; Gullino, M.L. First report of leaf spot of wild rocket (Diplotaxis tenuifolia) caused by Fusarium equiseti in Italy. Plant Dis. 2015, 99, 1183. [CrossRef]

114. Gilardi, G.; Garibaldi, A.; Gullino, M.L. Seed transmission of Plectosphaerella cucumerina, causal agent of leaf spot of Diplotaxis tenuifolia in Italy. Phytoparasitica 2013, 41, 411-416. [CrossRef]

115. Gilardi, G.; Pintore, I.; Gullino, M.L.; Garibaldi, A. Occurence of Fusarium equiseti as a contaminant of Diplotaxis tenuifolia seeds. J. Plant Pathol. 2017, 99, 245-248.

116. Chen, C.Y.; Séguin-Swartz, G. Reaction of wild crucifers to Leptosphaeria maculans, the causal agent of blackleg of crucifers. Can. J. Plant Pathol. 1999, 21, 361-367. [CrossRef]

117. Delourme, R.; Chévré, A.; Brun, H.; Rouxel, T.; Balesdent, M.; Dias, J.; Sailsbury, P.; Renard, M.; Rimmer, S. Major gene and polygenic resistance to Leptosphaeria maculans in oilseed rape (Brassica napus). Eur. J. Plant Pathol. 2006, 114, 41-52. [CrossRef]

118. Voorips, R.E. Plasmodiophora brassicae: Aspects of pathogenesis and resistance in Brassica oleracea. Euphytica 1995, 83, 139-146. [CrossRef]

119. Pennycook, S.R. Plant Diseases Recorded in New Zealand (2nd Vol); Plant Diseases Division, DSIR: Auckland, New Zealand, 1989; p. 502.

120. Buser, H.; Heller, W.E. Falscher mehltau an rucola: Noch keine lösung des problems in sicht. Der Gemüsebau 2006, 69, 11-12.

121. Westman, A.L.; Kresovich, S.; Dickson, M.H. Regional variation in Brassica nigra and other weedy crucifers for disease reaction to Alternaria brassicicola and Xanthomonas campestris pv. campestris. Euphytica 1999, 106, 253-259. [CrossRef] 
122. Raio, A.; Giorgini, M. Infezioni di Xantomonas campestris pv campestris in coltivazioni di rucola selvatica in Campania. Inf. Fitopatol. 2005, 55, 58-60.

123. Pernezny, K.; Raid, R.N.; Jones, J.B.; Dickstein, E. First report of a leaf spot disease of wild rocket (Diplotaxis tenuifolia) in Florida caused by Xanthomonas campestris pv. raphani. Plant Dis. 2007, 91, 1360. [CrossRef]

124. Amici, A.; Gracini, P.; Osler, R.; Refatti, E. Alterazioni a probabile eziologia da micoplasmi in varie specie di piante in Italia. Riv. Patol. Veg. 1972, 8, 21-50.

125. Stavolone, L.; Alioto, D.; Ragozzino, A.; Laliberté, J.F. Variability among turnip mosaic potyvirus isolates. Phytopathology 1998, 88, 1200-1204. [CrossRef] [PubMed]

126. Parrella, G.; Greco, B.; Troiano, E. First Report of Parietaria mottle virus associated with yellowing disease of Diplotaxis tenuifolia in Italy. Plant Dis. 2017, 101, 850. [CrossRef]

127. Lupo, R.; Castellano, M.A.; Savino, V. Virus della Diplotaxis erucoides D.C. in Puglia. Inf. Fitopatol. 1991, 41, $42-44$.

128. Parrella, G.; Gognalons, P.; Gebre-Selassiè, K.; Vovlas, C.; Marchoux, G. An update of the host range of tomato spotted wilt virus. J. Plant Pathol. 2003, 85, 227-264.

129. Gallitelli, D.; Rana, G.L.; Vovlas, C.; Martelli, G.P. Viruses of globe artichoke: An overview. J. Plant Pathol. 2004, 86, 267-281.

130. Scholze, P.; Krämer, R.; Ryschka, U.; Klocke, E.; Schumann, G. Somatic hybrids of vegetable brassicas as source for new resistances to fungal and virus disease. Euphytica 2010, 176, 1-14. [CrossRef]

131. Gómez-Merino, F.C.; Trejo-Téllez, L.I. Biostimulant activity of phosphite in horticulture. Sci. Hortic. 2015, 196, 82-90. [CrossRef]

132. Gilardi, G.; Demarchi, S.; Gullino, M.L.; Garibaldi, A. Management of leaf spot of wild rocket using fungicides, resistance inducers and a biocontrol agent, under greenhouse conditions. Crop Prot. 2015, 71, 39-44. [CrossRef]

133. Ciampolini, M.; Capella, A.; Farnesi, I. La tignola delle Crucifere insidia le coltivazioni di rucola. Inf. Agrar. 1998, 54, 69-72.

134. Ciampolini, M.; Capella, A.; Farnesi, I.; Mozzo, G. Hellula undalis pericoloso fitofago della rucola. Inf. Agrar. 2001, 57, 69-73.

135. Ciampolini, M.; Regalin, R.; Guarnone, A.; Farnesi, I. Diffusi e intensi attacchi di altiche (Phyllotreta spp.) su rucola. Inf. Agrar. 2001, 57, 87-91.

136. Raimo, F.; Miccio, G.; Nicoletti, R.; Janssens, F. Danni da Collemboli su rucola selvatica (Diplotaxis tenuifolia). Inf. Fitopatol. 2005, 55, 44-47.

137. Espinosa, B.; Sannino, L.; Conte, A.; Lista, A.; Del Grosso, M. Rucola non commerciabile per le mine di Scaptomyza flava. Inf. Agrar. 2010, 26, 60-61.

138. Farnesi, I.; Massi, E.; Ciampolini, M. Tipici danni da sciaridi su colture di rucola in serra. Inf. Agrar. 2005, 16, 71-74.

139. Solinas, M.; Bucci, M. An ecological investigation into flower galls on Diplotaxis muralis D.C. caused by the gall midge Paragephyraulus diplotaxis Solinas. Entomologica 1982, 17, 5-22.

140. Skuhrava, M.; Skuhravy, V. Gall midges (Diptera: Cecidomyiidae) of Italy. Entomologica 1994, 28, 45-76.

141. Shimat, J. Effects of insect growth regulators on Bagrada hilaris (Hemiptera: Pentatomidae). J. Econ. Entomol. 2017, 110, 2471-2477.

142. Laffi, F. Infestations of the mite Bryobia praetiosa on Diplotaxis tenuifolia. Inf. Agrar. 2001, 57, 83-84.

143. Giorgini, M. Un nuovo acaro dannoso alla coltura di rucola selvatica in Campania. Inf. Fitopatol. 2001, 51, 88-91.

144. Vidovic, B.; Cvrkovic, T.; Maric, I.; Chetverikov, P.E.; Cristofaro, M.; Rector, B.G.; Petanovic, R. A new Metaculus species (Acari: Eriophyoidea) on Diplotaxis tenuifolia (Brassicaceae) from Serbia: A combined description using morphology and DNA barcode data. Ann. Entomol. Soc. Am. 2015, 108, 922-931. [CrossRef]

145. Fuller, E.; Elderd, B.D.; Dwyer, G. Pathogen persistence in the environment and insect-baculovirus interactions: Disease-density thresholds, epidemic burnout and insect outbreaks. Am. Nat. 2012, 179, E70-E96. [CrossRef] [PubMed]

146. Spadafora, N.D.; Amaro, A.L.; Pereira, M.J.; Müller, C.T.; Pintado, M.; Rogers, H.J. Multi-trait analysis of post-harvest storage in rocket salad (Diplotaxis tenuifolia) links sensorial, volatile and nutritional data. Food Chem. 2016, 211, 114-123. [CrossRef] [PubMed] 
147. Cornacchia, R.; Rinaldi, R.; Quinto, M.; Colelli, G. Foglie di rucola: L'effetto sulla qualità della conservazione in AC. Colt. Prot. 2006, 35, 83-87.

148. Luca, A.; Bach, V.; Edelenbos, M. Optimization of headspace solid-phase microextraction and static headspace sampling of low-boiling volatiles emitted from wild rocket (Diplotaxis tenuifolia L.). Food Anal. Methods 2015, 8, 1185-1196. [CrossRef]

149. Luca, A.; Mahajan, P.V.; Edelenbos, M. Changes in volatile organic compounds from wild rocket (Diplotaxis tenuifolia L.) during modified atmosphere storage. Postharvest Biol. Technol. 2016, 114, 1-9. [CrossRef]

150. Jin, J.; Koroleva, O.A.; Gibson, T.; Swanston, J.; Magan, J.; Zhang, Y.; Rowland, I.R.; Wagstaff, C. Analysis of phytochemical composition and chemoprotective capacity of rocket (Eruca sativa and Diplotaxis tenuifolia) leafy salad following cultivation in different environments. J. Agric. Food Chem. 2009, 57, 5227-5234. [CrossRef] [PubMed]

151. Seefeldt, H.F.; Løkke, M.M.; Edelenbos, M. Effect of variety and harvest time on respiration rate of broccoli florets and wild rocket salad using a novel $\mathrm{O}_{2}$ sensor. Postharvest Biol. Technol. 2012, 69, 7-14. [CrossRef]

152. Sinigaglia, M.; Albenzio, M.; Corbo, M.R. Influence of process operations on shelf-life and microbial population of fresh-cut vegetables. J. Ind. Microbiol. Biotechnol. 1999, 23, 484-488. [CrossRef]

153. Galli, A.; Franzetti, L. La sicurezza igienico-sanitaria degli ortaggi di IV gamma. Inf. Agrar. 1998, 54, 46-47.

154. Aruscavage, D.; Lee, K.; Miller, S.; Lejeune, J.T. Interactions affecting the proliferation and control of human pathogens on edible plants. J. Food Sci. 2006, 71, R89-R99. [CrossRef]

155. Golberg, D.; Kroupitski, Y.; Belausov, E.; Pinto, R.; Sela, S. Salmonella typhimurium internalization is variable in leafy vegetables and fresh herbs. Int. J. Food Microbiol. 2011, 145, 250-257. [CrossRef] [PubMed]

156. Villari, P.; Crispino, M.; Montuori, P.; Stanzione, S. Prevalence and molecular characterization of Aeromonas spp. in ready-to-eat foods in Italy. J. Food Prot. 2000, 63, 1754-1757. [CrossRef] [PubMed]

157. Marchetti, R.; Casadei, M.A.; Guerzoni, M.E. Microbial population dynamics in ready-to-use vegetable salads. Ital. J. Food Sci. 1992, 2, 97-108.

158. Martínez-Sánchez, A.; Allende, A.; Bennett, R.N.; Ferreres, F.; Gil, M.I. Microbial, nutritional and sensory quality of rocket leaves as affected by different sanitizers. Postharvest Biol. Technol. 2006, 42, 86-97. [CrossRef]

159. Kader, A.A. Biochemical and physiological basis for effect of controlled and modified atmosphere on fruit and vegetables. Food Technol. 1986, 40, 99-100.

160. Martínez-Sánchez, A.; Marín, A.; Llorach, R.; Ferreres, F.; Gil, M.I. Controlled atmosphere preserves quality and phytonutrients in wild rocket (Diplotaxis tenuifolia). Postharvest Biol. Technol. 2006, 40, 26-33. [CrossRef] 